\title{
Bilateral Wrist Drop Complicating Axillary Crutches Mobilization in a Young Adult

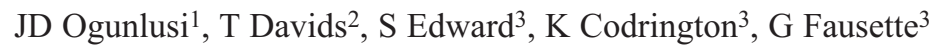

\begin{abstract}
Objective: Axillary crutches are simple rehabilitative devices that are globally used temporarily or permanently to assist in ambulation of patients and rarely present with complication. This report is about bilateral wrist drop incidentally noticed in a young adult patient mobilized on axillary crutches after internal fixation of a simple right tibia fracture.

Methods: The fracture was fixed by intramedullary nailing and the patient was mobilized on axillary crutches. At six weeks, patient fearfully refused to be commenced on partial weight bearing and at 12 weeks after surgery he was noticed to be totally weightbearing on the bars of the appropriately long axillary crutches and had developed bilateral wrist drop. There was radiological evidence of healing at the fracture sites. Treatment included mobilization on one elbow crutch on the left, physical therapy and nerve stimulation.

Results: At six weeks of physiotherapy, the power of the dorsiflexors of the wrists had recovered completely.

Conclusion: Bilateral posterior cord palsy of brachial plexus could occur even in young healthy patients but total recovery could occur if the diagnosis and treatment are prompt. Patients should be told in unequivocal terms not to weight bear directly on axillary bars.
\end{abstract}

Keywords: Axillary crutches, wrists drop

\section{Mano Péndula Bilateral que Complica la Movilización con Muletas Axilares en un Adulto Joven \\ JD Ogunlusi ${ }^{1}$, T Davids 2 , S Edward ${ }^{3}, \mathrm{~K}_{\text {Codrington }}^{3}$, G Fausette ${ }^{3}$}

\begin{abstract}
RESUMEN
Objetivo: Las muletas axilares son simples dispositivos de rehabilitación que se utilizan en todo el mundo de manera temporal o permanentemente para ayudar a caminar a los pacientes, y raramente presentan complicación. Este trabajo trata de la mano péndula o mano caída, observada incidentalmente en un paciente adulto joven movilizado en muletas axilares, después de la fijación interna de una fractura simple de la tibia derecha.

Métodos: La fractura fue fijada mediante clavo intramedular, y el paciente fue movilizado con muletas axilares. A las seis semanas, el paciente se negó temeroso a la iniciación para sostener parcialmente todo su peso con ayuda de muletas, y a las 12 semanas después de la cirugía, se le vio sostener todo su peso sobre las barras de las muletas axilares de longitud adecuada, y había desarrollado mano péndula bilateral. Había evidencia radiológica de curación en los sitios de fractura. El tratamiento incluyó la movilización con una muleta de codo a la izquierda, terapia fisica, y estimulación nerviosa.
\end{abstract}

From: ${ }^{1}$ Accident and Emergency Unit, ${ }^{2}$ Orthopaedic Unit and ${ }^{3}$ Physiotherapy Unit, Victoria Hospital, Castries, St Lucia, West Indies.
Correspondence: Dr JD Ogunlusi, Accident and Emergency Unit, Victoria Hospital, Castries, St Lucia, West Indies. E-mail: gbemidare@yahoo.com 
Resultados: A las seis semanas de fisioterapia, la capacidad de los dorsiflexores de las muñecas se había recuperado completamente.

Conclusión: La parálisis del fascículo posterior bilateral del plexo braquial podría ocurrir incluso en pacientes jóvenes sanos, pero la recuperación total podría ocurrir si el diagnóstico y el tratamiento se hacen a tiempo. A los pacientes se les debe decir en términos inequivocos que no deben soportar todo su peso directamente en las barras axilares.

Palabras claves: Muletas axilares, mano péndula

\section{INTRODUCTION}

Axillary crutches mobilization rarely present with complications but when they do, diagnosis could be late and may require prolonged treatment and may have a poor prognosis. This report is about bilateral wrist drop incidentally noticed in an orthopaedic outpatient clinic in an adult patient mobilized on axillary crutches after internal fixation of a simple tibia fracture. The rarity of this case prompted the reporting and also the observation that a very high index of suspicion is needed to make the diagnosis. Literature review (PubMed) showed three reported cases of bilateral posterior cord/radial nerve palsy secondary to axillary crutches compression over the past sixty years. The review also showed that bilateral crutches palsy of the posterior cord of the brachial plexus is rare in adults but has been reported in children and patients with neurological diseases like poliomyelitis who were not using the axillary crutches properly $(1,2)$.

\section{Brief anatomy of brachial plexus}

The Figure shows a diagrammatic representation of the formation of the brachial plexus in the axilla. The brachial

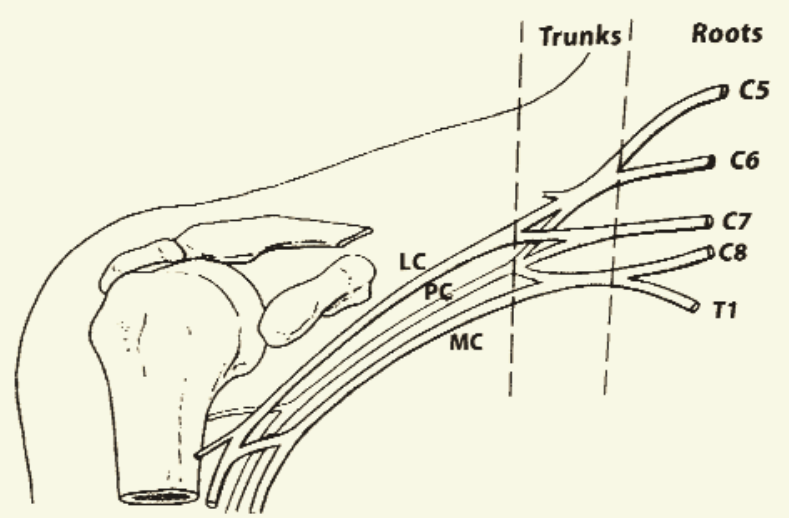

Figure: Formation of the brachial plexus.

$\mathrm{C}=$ cervical; $\mathrm{T}=$ thoracic $; \mathrm{LC}=$ lateral $\operatorname{cord} ; \mathrm{PC}=$ posterior cord; $\mathrm{MC}=$ medial cord

plexus is formed by the nerve roots of $\mathrm{C} 5$ to $\mathrm{T} 1$ forming the trunks, divisions, cords and nerves. Trunks subdivide to form lateral, medial and posterior cords. The roots of $\mathrm{C} 5$ and $\mathrm{C} 6$ merge to form the upper trunk. The $\mathrm{C} 7$ root forms the middle trunk and the roots of $\mathrm{C} 8$ and $\mathrm{T} 1$ merge to form the lower trunk.
The upper trunk divides and gives branches to the lateral and posterior cords. The middle trunk divides and gives branches to the lateral and posterior cords. The lower trunk divides and gives branches to the posterior and medial cord. The lateral cord branches and gives rise to the musculocutaneous nerve and contributes to the median nerve. The posterior cord branches and gives rise to the axillary nerve and then becomes the radial nerve. The medial cord branches and contributes to the median nerve and then becomes the ulnar nerve.

A very high lesion of the radial nerve may be caused by trauma or operation around the shoulder or compression of the posterior cord in the axilla. This is seen in alcoholics and drug addicts who fall in a stupor with the arm dangling over the back of a chair (Saturday night palsy) or in thin elderly patients using crutches [crutch palsy] (3).

\section{CASE REPORT}

An 18-year old male sustained closed undisplaced fractures of the lower third of the right tibia and of the upper third of the right fibula while playing with a friend at home. He had intramedullary interlocking nailing with Surgical Implant Generation Network (SIGN) nail 10 days after the injury and was discharged home on bilateral axillary crutches three days after surgery. On the eighteenth postoperative day, he was noticed to have developed wound infection, and wound culture revealed Staphylococcus aureus sensitive to clindamycin. Complete blood count was essentially normal but erythrocyte sedimentation rate was $31 \mathrm{~mm}$ per hour (Westergren). The infection was treated aggressively as a case of osteomyelitis; the patient was placed on clindamycin $300 \mathrm{mg}$ six hourly daily for six weeks and the infection cleared.

The patient was on axillary crutches for three months after the surgery; he was initially seen at the outpatient clinic three times, at two and a half weeks, six weeks and at 12 weeks postsurgery. All efforts to commence him on partial weightbearing at six weeks postoperatively failed. On the third outpatient clinic visit, he was noticed to be totally weight-bearing on the bars of the appropriately long axillary crutches. It was also observed that the patient had selfprescribed bilateral wrist splints which on removal revealed bilateral wrist drop. The power of dorsiflexion of the right wrist was $1 / 5$ and the left was $4 / 5$. There was no sensory impairment in the two upper limbs. Nerve conduction test 
and electromyography could not be done because of unavailability. There was no history of any chronic musculoskeletal diseases. He was mentally normal and answered all questions intelligently. Thorough examination did not reveal any abnormal musculoskeletal pathology apart from the wrist drop and the fracture of the tibia. There was satisfactory radiological evidence of healing at the fracture sites and no evidence of chronic osteomyelitis at 12 weeks. A diagnosis of bilateral wrist drop secondary to posterior cord compression from bilateral axillary crutches was made.

He was immediately referred to the physiotherapy department to be completely weaned off the axillary crutches and to have physical therapy. The patient was mobilized on one elbow crutch on the left. He had nerve stimulation twice per week for a duration of two weeks, constant bilateral wrist splints and heat therapy. The physical therapy was in the form of progressive resistive range of motion exercise. At four weeks after commencement of physiotherapy, the power of the wrists dorsiflexion had improved to $4 / 5$ on the right and $5 / 5$ on the left and power of the extensor pollicis longus was $3 / 5$ on the right. After six weeks of physiotherapy, the power of the dorsiflexors of the wrists had recovered completely and the right extensor pollicis longus had also fully recovered.

\section{DISCUSSION}

Axillary crutches are simple rehabilitative devices that are globally used temporarily or permanently to assist in ambulation of patients. They are widely used in orthopaedics for relieving weightbearing on operated or injured legs for the purpose of ambulation. The use of the device is not without complications and misuse of these simple axillary crutches can result in rare catastrophic complications $(4,5)$. The complications that have been reported are mainly neurovascular and these include: life threatening complications like recurrent embolism, caused by an axillary crutch-induced aneurysm of the axillary artery due to crutch-induced repetitive trauma and non-life threatening complications like long thoracic and radial nerve palsies $(2,6-8)$. The radial nerve and axillary artery are the commonest structures injured by the long term use of axillary crutch (9). These complications are usually as a result of direct and inappropriate placement of body weight on the axillary pads as was noticed in this patient $(4,9)$. It has been stated that, although axillary crutch palsy is well-described in the literature, it is rarely seen in clinical practice (10). A few cases of bilateral posterior cord compressive neuropathy have been reported previously by some authors $(2,10)$. One of the reported cases had little improvement clinically at eight weeks after the estimated onset of the palsy, due to a severe axonotmesis lesion of the radial, median, and ulnar nerves which was confirmed by electromyogram (2). Recovery was not until nine months after the diagnosis of the palsy (2). In our case report, recovery was complete at six weeks post diagnosis of the palsy; this could be due to early diagnosis and prompt treatment. The patient was commenced on active therapy which included physical therapy, nerve stimulation and ultrasound to the muscles. This recovery time was similar but quicker by two weeks to the case reported by Poddar et al (10). This case shows that quick and full recovery is possible if early diagnosis is made and early treatment is commenced. Sen-sation is rarely affected by the radial nerve compression but motor weakness may become worse and may lead to com-plete paralysis of the triceps and forearm extensor muscles (11).

Although diagnosis of traumatic brachial plexus compression due to axillary crutches should be made clinically, nerve conduction test could be used to confirm the conduction block. This conduction test and electromyography has been used by other authors to confirm the diagnosis, determine the severity and follow-up the patients with peripheral neuropathies $(1,12)$.

A delayed or missed diagnosis in this patient would have led to prolonged or permanent disability and serious consequences because the involvement of the two hands would have grossly affected his productivity. The diagnosis of this very rare complication of axillary crutches mobilization calls for a high index of suspicion. Review of a patient on crutches in an outpatient clinic should be thorough in order not to miss occult pathology such as this.

These axillary crutches induced injuries are preventable, thus patients should be told and counselled on the risk of bearing weight inappropriately on the bars of the devices. The person issuing the crutches should explain and demonstrate the proper use of the crutches. Patients should be given clear instructions on climbing and descending stairs and the technique of sitting and arising (11). It has also been reported that this type of injury could be prevented by using elbow crutches (13).

In summary, it was observed that bilateral posterior cord palsy of the brachial plexus could occur even in young healthy patients and total recovery of the damaged nerve could occur if the diagnosis and treatment are prompt but it should be borne in mind that prevention is better than cure. Thus, patients should be told in unequivocal terms not to directly weight bear on axillary bars.

\section{REFERENCES}

1. Veerendrakumar M, Taly AB, Nagaraja D. Ulnar nerve palsy due to axillary crutch. Neurol India 2001; 49: 67-70.

2. Raikin S, Froimson MI. Bilateral brachial plexus compressive neuropathy (crutch palsy). J Orthop Trauma 1997; 11: 136-8.

3. Milanes-Ruges G, Foyaca-Sibat H, Ibañez-Valdés L, Rodriguez-Neyra M. Brachial plexus: our anatomical findings (Part I). Internet J Neurol 2008; 9. DOI: $10.5580 / \mathrm{fbf}$.

4. Goh JC, Toh SL, Bose K. Biomechanical study on axillary crutches during single-leg swing-through gait. Prosthet Orthot Int 1986; 10: 8995.

5. Levin P. Ambulatory assistance devices in orthopaedic: uses and modifications. J Am Acad Orthop Surg 2010; 18: 315-6.

6. Danese CA, Voleti DC, Baron MG, Waye JD, Jacobson JH Jr. Recurrent embolism from an occult crush aneurysm of the axillary artery. Surg 1969; 66: 860-2. 
7. Moon IS, Hwang JK, Kim JI. Recurrent upper extremity embolism due to a crutch-induced arterial injury: a different cause of upper extremity embolism. Ann Vasc Surg 2010; 24: 554.e7-554.e12.

8. Murphy MT, Journeaux SF. Case reports: long thoracic nerve palsy after using a single axillary crutch. Clin Orthop Relat Res 2006; 447: 267-9.

9. McFall B, Arya N, Soong C, Lee B, Hannon R. Crutch induced axillary artery injury. Ulster Med J 2004; 73: 50-2.
10. Poddar SB, Gitelis S, Heydemann PT, Piasecki P. Bilateral predominant radial nerve crutch palsy. A case report. Clin Orthop Relat Res 1993; 297: 245-6.

11. Jebsen RH. Use and abuse of ambulation aids. JAMA 1967; 199: 5-10.

12. Huynh W, Kiernan MC. Nerve conduction studies. Aust Fam Physician 2011; 40: 693-7.

13. Stallard J, Sankarankutty M, Rose GK. A comparison of axillary, elbow and Canadian crutches. Rheumatol Rehabil 1978; 17: 237-9. 